\title{
DRAFT February 3, 2004
}

\section{Design Guide for Renewable Energy Certificate Tracking Systems}

National Wind Coordinating Committee

Green Markets and Credit Trading Work Group

February, 2004

Please note: This draft resource document of the National Wind Coordinating Committee is still under review. Comments on the draft are invited and should be sent to Kevin Bryan, Senior Outreach Coordinator for the NWCC, at kbryan@ resolv.org; or to Ed Holt, Chair of the Green Markets and Credit Trading Work Group, at edholt@igc.org. 

Table of Contents

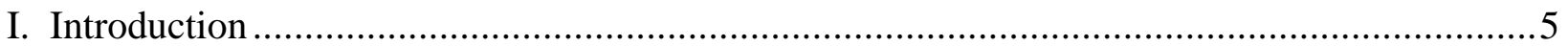

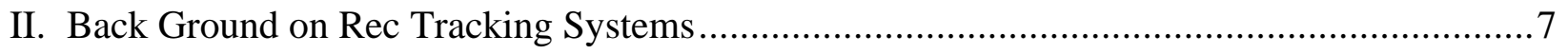

Need for REC Tracking Systems ...................................................................... 7

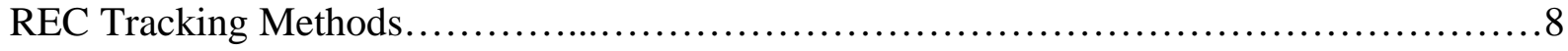

operation of Certificate-Based Tracking Systems ..................................................... 9

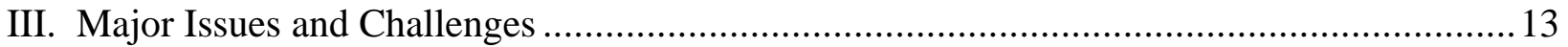

Pros and Cons of RECs-Only and All Generation Tracking Systems ............................... 13

Geographic Scope of Tracking Systems ............................................................. 16

REC Imports and Exports and Tracking Systems Coordination .................................... 17

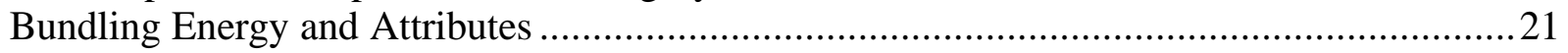

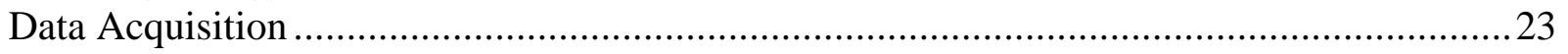

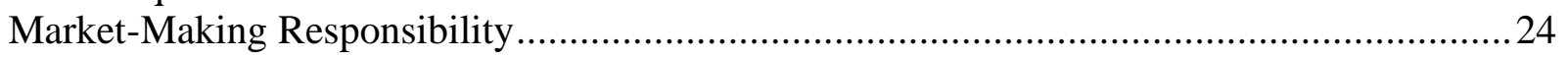

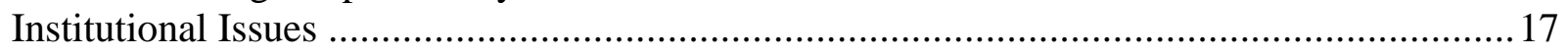

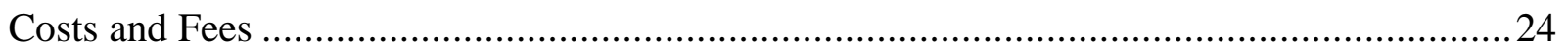

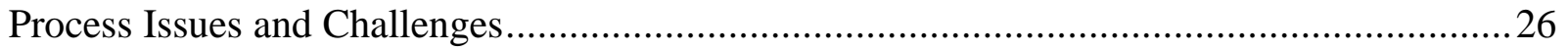

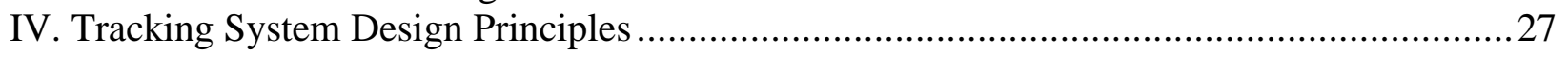

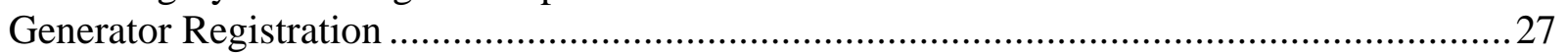

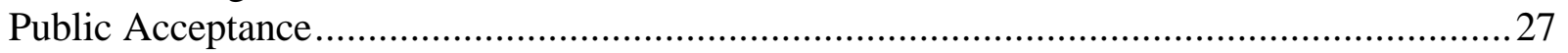

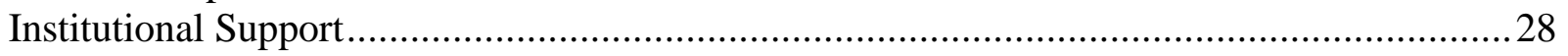

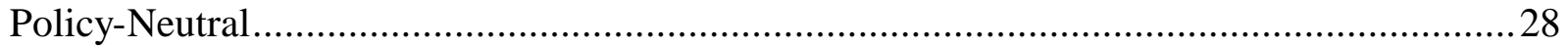

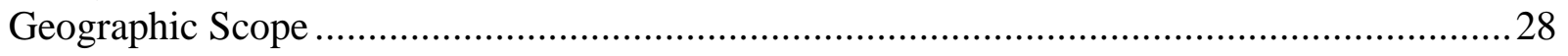

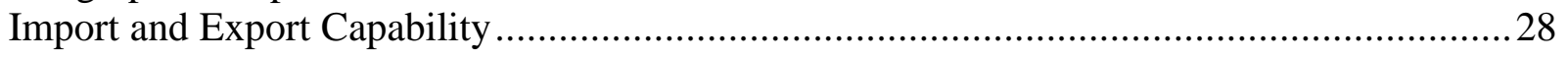

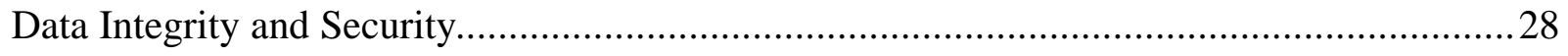

Low Transaction Costs..................................................................................... 29

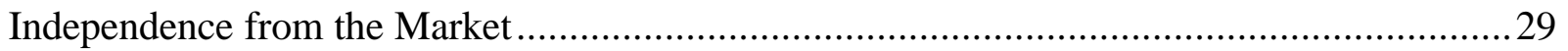

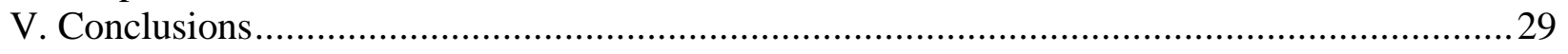

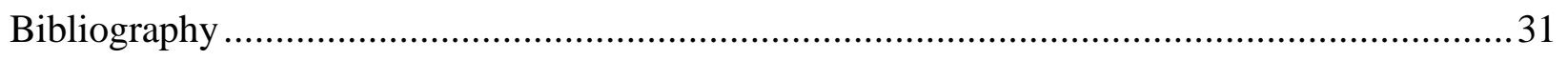

DRAFT 2/03/04 Page 3 
NWCC REC Tracking System Design Guide

DRAFT 2/03/04

Page 4 


\section{Introduction}

Markets for renewable energy certificates (RECs) are expanding rapidly in the U.S. and throughout the world. RECs were originally proposed in 1996 as an accounting or verification mechanism for required disclosure of the fuel sources of generation in retail electricity products. It was suggested that by unbundling the resource attributes from the associated electricity, the attributes could be traded more efficiently.

This idea took root, and now the use of RECs is growing for the same reason they were first proposed: RECs help overcome many barriers to buying and selling renewable energy attributes bundled with electricity. These barriers include transmission access and pricing policies, resource intermittency, mismatches between the timing of generation and demand, and lack of market liquidity, among others. ${ }^{1}$

The volume of RECs traded is difficult to estimate, because much of the trading is in wholesale markets that are hard to monitor, and because some RECs are rebundled with electricity and sold as green power. Market participants are more visible than the volume of trading, and now number about 40 firms, including brokers, trading RECs.

\section{Markets for RECs}

RECs have been adapted to a variety of markets. Some of these markets overlap, but they can be thought of as the following:

- Wholesale and retail markets

- Compliance and voluntary markets

- Energy and environmental markets

- Different geographic markets

For example, RECs are now used extensively in wholesale markets. Initially, in 1998-2000, Automated Power Exchange created and operated a wholesale market in California based on RECs. As of January 2004, there are 18 active wholesale RECs marketers listed by the Green Power Network. Utilities and marketers frequently purchase RECs in wholesale markets and then rebundle them with commodity electricity to create green power for retail customers. When used this way, REC sales are largely invisible.

RECs are also sold in retail markets as a stand-alone unbundled product. There are at least 18 retail RECs marketers listed by the Green Power Network. Some began by selling RECs over the Internet, and several now sell RECs in partnership with electricity distribution companies, such as Niagara Mohawk and Mass Electric. Individuals and households can buy RECs, and large consumers especially have demonstrated an appetite for RECs to them meet corporate environmental goals. ${ }^{2}$

\footnotetext{
${ }^{1}$ However, RECS alone cannot overcome all barriers, for example, those caused by poor scheduling protocols or inadequate transmission.

${ }^{2}$ Hanson, Craig and Vince Van Son, Renewable Energy Certificates: An Attractive Means For Corporate Customers To Purchase Renewable Energy. Washington, DC: World Resources Institute, 2003.
} 
REC markets are also defined by their motivation. For example, public policy is a driver of REC trading in compliance markets. Renewable portfolio standards and electricity environmental disclosure requirements may rely on RECs to verify compliance. An alternative motivation is product or company differentiation in voluntary markets. Whether offering RECs as a stand-alone product or RECs rebundled with energy as green power, marketers can substantiate their marketing claims using REC ownership as proof.

Beyond the energy-related markets mentioned above, interest in RECs has also grown because renewable energy (and by extension, RECs) may be able to participate in environmental markets if wind and other renewables are eligible to earn emissions allowance or credits. Much more work needs to be done in this area, but in the U.S potential environmental markets include mandated NOx, SO2, and possibly mercury cap-and-trade programs, as well as voluntary carbon markets.

Even without these market differences, there are distinct geographic markets for RECs. Some markets, for example, are defined by states in relation to policy mandates, while other markets are regional based on power pools and the location of generation that created the RECs. There are also national (and international) markets in the sense that consumers anywhere can buy RECs over the Internet independent of their utility or electricity provider.

\section{Purpose}

In recognition of these growing markets, the National Wind Coordinating Committee (NWCC) has focused on a key element of the infrastructure for REC markets: certificate-based tracking systems. The NWCC is interested in REC tracking systems because wind is a primary beneficiary of REC sales, with nearly 6,400 MW of installed capacity in the U.S. at the end of 2003.

In 2001 the NWCC adopted by consensus its Credit Trading Opportunities and Guidelines, including the following:

Creation of a renewable energy credit registry (one national or multiple regional registries), or another comparable mechanism, would allow the recognition of attributes from renewable generation, help to avoid double counting, and help to cope with cross-jurisdictional "seams" issues.

Since then, several REC and all-generation tracking systems have been developed in the U.S. and internationally, and there are several others under development. The experience gained to date in the development of these systems has helped to identify key issues in the design of 
tracking systems. The purpose of this Design Guide is to highlight these issues and lessons learned and thereby to assist in the continued development of regional certificate-based tracking systems.

The NWCC hopes that the Design Guide will be useful to policy-makers, regulators and other stakeholders in regional discussions about tracking system design and development, with the ultimate goal of reliable, credible and robust certificate markets.

\section{Outline}

Beyond this introduction, the Design Guide is presented in three parts. Section II describes the need for REC tracking, the two principal tracking methods available, and, in simple terms, the operation of certificate-based systems. Section III presents the major issues in the design of certificate-based tracking systems and discusses the advantages and disadvantages of alternative solutions. Finally, Section IV offers design principles or recommendations for most of these issues.

\section{Background on REC Tracking}

\section{Need for REC Tracking}

Electricity markets are complex, but over the years systems have been developed to provide for a financial settlement of who owes whom what amount of money at the end of the day. Although one cannot track electrons, one can at least determine whether electricity service was provided. That system does not function for RECs if they are traded separately from electricity.

There are a variety of reasons why RECs should be tracked:

- Although transactions usually involve RECs created within the year they were issued, RECs may be banked and borrowed, though specific programs may restrict such activity. Thus transactions may occur using REC created in previous years (banked RECs) or using RECs to be generated in future years (borrowed RECs). An accounting system would help keep track of these inter-temporal transactions.

- If RECs are transacted through multiple parties, it may be confusing or unclear who gets to claim the benefits. Double claims on the same REC may be inadvertent or intentional, but if someone were inclined to fraud, it would be fairly easy to sell the same REC to more than one party.

- REC marketers, unless they are also selling electricity at retail, generally do not fall under the jurisdiction of state Public Utility Commissions. Regulators do play a role if load serving entities must comply with an RPS or electricity labeling requirements, but many uses of RECs are not monitored, especially RECs transacted in wholesale markets and unbundled RECs sold in retail markets. 
Even for regulated programs such as an RPS or electricity labeling, there is a question of how to verify compliance with the programs, and even in voluntary markets, marketers must be able to substantiate green marketing claims.

\section{Double Counting}

Double counting is the use of a REC by more than one party at the same time, or by one party for more than one purpose. Double counting may take several forms:

- Double sale: A REC is sold to two different parties at the same time.

- Double claim: More than one party claims the renewable benefits from the same REC, most likely by purchasing it one after the other.

- Double use: A single party owns the REC and uses it for two purposes, such as for compliance with an RPS and to support a voluntary green marketing claim, or for a green marketing claim and to earn an emissions reduction credit.

The term double counting is rooted in the concept of "additionality" often used in environmental markets, meaning that a public policy or a voluntary purchase of green attributes creates additional demand for renewable energy and leads to incremental environmental benefits.

\section{REC Tracking Methods}

There are two principal methods to verify RECs ownership: contract audits and certificates-based tracking systems.

\section{Contract Audits}

One method is to conduct an independent audit of the chain of custody for RECs using contracts from the original owner (presumably the generator) through to the final owner (most likely the retail marketer). This has sometimes been called the contract-path method of verification. The audit could be done using either power sales contracts if the RECs have been sold bundled with electricity, or RECs contracts if they are sold unbundled.

If RECs are sold bundled with electricity, the independent system operator or other entity responsible for system dispatch and financial settlements may know the contract path, but even with the cooperation of this grid operator, such tracking may be cumbersome and expensive. In the absence of a tracking system or central entity responsible for financial settlements, it is extremely difficult to track source-specific property rights through a commodity electricity market.

If the RECs are unbundled and sold through contracts separate from electricity contracts, the grid operator is not in a position to support tracking REC ownership. In this case, REC contracts will be scattered among all the intermediary parties and would be more expensive to audit.

Even though a contract audit is presumably done by an independent third party, the audit process introduces an element of subjective evaluation into the verification method. Third party audits 
are also extremely labor-intensive and therefore are not a very practical or efficient way of tracking the hundreds or thousands of transactions that take place.

Another disadvantage to contract-path verification is that it is unable to check for double selling or double counting system-wide because in each audit, the auditor is only looking at a piece of the total market (i.e., auditing one supplier). As a result, it is very difficult for a regulatory body to ensure that no double selling or double counting of RECs is occurring.

\section{Certificate-based Tracking Systems}

The drawbacks to verification by contract audit help focus on one of the key advantages of certificate-based tracking: the possession of the electronic certificate itself is proof of ownership, eliminating the need to track ownership through the chain of intermediaries in energy and nonenergy transactions.

Audits to verify ownership of RECs for compliance or for voluntary marketing claims are greatly facilitated by a certificates-base accounting system. In fact, the audit is almost entirely automated. With the growing volume of REC transactions, it makes sense to automate verification.

Certificate-based tracking systems further help to address issues related to consumer confidence and credibility of the RECs being purchased. The creation of formal records of generation that have the endorsement and backing of state regulatory agencies or system operators effectively establishes property rights for certificate buyers. This greatly reduces the risks of double counting or double selling for market participants, consumers and regulators.

Because they are automated, certificate-based tracking systems are very flexible and can be easily expanded to track many different kinds of information about generating facilities. Certificate-based systems can be designed with a wide variety of features to accommodate multiple regulatory environments and market needs within a region.

For these reasons, certificate-based tracking has emerged as the most common method for accounting for renewable generation and for preventing double counting of RECs. In addition to Texas, New England, and Wisconsin, where certificate-based accounting systems are already in operation, certificate-accounting systems are under development in California and the wider Western Electricity Coordinating Council, and are being contemplated for the Mid-Atlantic (PJM) region, Minnesota, New York and Ontario. ${ }^{3}$ Several of these, plus European and Australian certificate tracking systems, are summarized in Table 1.

\section{Operation of Certificate-Based Tracking Systems}

In every case to date, tracking systems have been developed and implemented so that certificates can be sold separately from the electricity. Thus, an important feature of certificate-based accounting systems is the unbundling of renewable attributes from energy sales.

\footnotetext{
${ }^{3}$ Nevada and New York also have scaled-down versions of a certificate-based verification system in place. These states are not included in the discussion or in Table 1 because they are not automated, and rely on a manual verification of contracts and attestations.
} 
Certificate tracking systems generally refer to an electronic accounting system whereby the generation data, usually recorded by the independent system operator (ISO) or other dispatch control center, forms the basis for issuing RECs. The generation data used can be based on financial settlements or gross generation depending on the rules of the program.

Certificates are issued by the program administrator for each unit of electricity generated, usually denominated in MWh. Certificates are then deposited into the certificate owner's account. Usually the first point of deposit is the generator.

Once issued, certificates can be traded and transferred easily regardless of the actual energy flow. Both the buyer and seller must confirm the transaction (e.g., quantity and serial numbers) before a change in ownership is recorded in the system.

Certificate retirement can be implemented automatically by the program administrator per the rules of a state or regulatory program, such as an RPS, or voluntarily by certificate owners. Certificate tracking systems typically retire certificates under a variety of circumstances:

- when they are used to meet a regulatory requirement such as an RPS;

- when they are used to support a voluntary green power marketing claim;

- when they are claimed as part of a retail electricity disclosure label;

- when they are sold to an end-use customer; or

- when they are exported out of the system.

Generally speaking, a "retired" designation simply means that the certificate has been taken out of the trading market, indicating it has been finally "consumed." In this way, certificate systems are able to track all certificates generated and "consumed" to ensure that no certificate is used more than once. ${ }^{4}$

\footnotetext{
${ }^{4}$ When a REC is claimed by more than one party, or is used to satisfy more than one application (such as an RPS and a voluntary green marketing claim) it is generally referred to as double-counting. For more detail on doublecounting and its variations, see J. Hamrin and M. Wingate, Regulator's Handbook on Tradable Renewable Certificates. San Francisco: Center for Resource Solutions, 2003.
} 
Table 1. Comparison of Existing RECs Tracking Systems

\begin{tabular}{|c|c|c|c|c|c|c|}
\hline & $\begin{array}{l}\text { Texas Renewable } \\
\text { Energy Credit (REC) } \\
\text { Program }\end{array}$ & $\begin{array}{l}\text { NEPOOL Generation } \\
\text { Information System } \\
\text { (GIS) }\end{array}$ & $\begin{array}{l}\text { WI Renewable } \\
\text { Resource Credit } \\
\text { (RRC) }\end{array}$ & $\begin{array}{l}\text { PJM Generation } \\
\text { Attribute Tracking } \\
\text { System (GATS) } \\
\text { (Proposed) }\end{array}$ & $\begin{array}{l}\text { European } \\
\text { Renewable Energy } \\
\text { Certificate System } \\
\text { (RECS) }\end{array}$ & $\begin{array}{l}\text { Australia Office } \\
\text { of Renewable } \\
\text { Energy Regulator } \\
\text { (ORER) Registry }\end{array}$ \\
\hline $\begin{array}{l}\text { Type of } \\
\text { Generation } \\
\text { Tracked }\end{array}$ & $\begin{array}{l}\text { Existing and new } \\
\text { renewable generation }\end{array}$ & $\begin{array}{l}\text { All generation in or } \\
\text { delivered to NEPOOL } \\
\text { dispatch and control area }\end{array}$ & $\begin{array}{l}\text { Renewable } \\
\text { generation delivered } \\
\text { in excess of state } \\
\text { RPS requirement }\end{array}$ & $\begin{array}{l}\text { All generation in PJM } \\
\text { Control Area }\end{array}$ & $\begin{array}{l}\text { Existing and new } \\
\text { renewable } \\
\text { generation* }\end{array}$ & $\begin{array}{l}\text { Existing and new } \\
\text { renewable } \\
\text { generation }\end{array}$ \\
\hline $\begin{array}{l}\text { System } \\
\text { Overview }\end{array}$ & $\begin{array}{l}\text { - RECs are issued based } \\
\text { on settlement data \& } \\
\text { deposited in generator } \\
\text { accts. } \\
\text {-RECs are traded per } \\
\text { privately arranged } \\
\text { contracts } \\
\text {-RECs transfers occur } \\
\text { electronically, initiated by } \\
\text { participants } \\
\text {-RPS compliance is } \\
\text { verified via REC } \\
\text { ownership at end of } \\
\text { compliance period } \\
\text { - RECs are retired after } \\
\text { they are used to meet } \\
\text { RPS compliance }\end{array}$ & $\begin{array}{l}\text { - Certificates are issued } \\
\text { based on settlement data } \\
\text { \& deposited in generator } \\
\text { accts. } \\
\text {-Certificates are traded } \\
\text { per privately arranged } \\
\text { contracts } \\
\text {-Certificate transfers } \\
\text { occur electronically, } \\
\text { initiated by participants } \\
\text { - At end of compliance } \\
\text { period, all unsold } \\
\text { certificates are assigned } \\
\text { the "residual mix" and are } \\
\text { retired; all certificates in } \\
\text { LSE accounts used to } \\
\text { calculate disclosure label } \\
\text { or verify compliance w/ } \\
\text { RPS or GPS }\end{array}$ & $\begin{array}{l}\text {-RRCs are issued for } \\
\text { any amount of RE } \\
\text { generation delivered } \\
\text { in excess of an LSEs } \\
\text { RPS obligation } \\
\text {-RRCs are traded per } \\
\text { private contracts } \\
\text { - RRC transfers occur } \\
\text { electronically, initiated } \\
\text { by participants } \\
\text {-At end of compliance } \\
\text { period, all RRCs used } \\
\text { to meet RPS are } \\
\text { retired. }\end{array}$ & $\begin{array}{l}\text { - RECs will be issued } \\
\text { based on settlement } \\
\text { data \& deposited in } \\
\text { generator accounts } \\
\text {-RECs are traded per } \\
\text { private contracts } \\
\text {-REC transfers initiated } \\
\text { by participants } \\
\text {-RPS compliance is } \\
\text { verified via REC } \\
\text { ownership at end of } \\
\text { compliance period } \\
\text {-Program administrator } \\
\text { will identify percentages } \\
\text { for "spot market mix" to } \\
\text { be used on env. } \\
\text { disclosure labels, } \\
\text { system will issue } \\
\text { disclosure labels for } \\
\text { utilities and other } \\
\text { participants }\end{array}$ & $\begin{array}{l}\text {-RECS is an extra- } \\
\text { governmental } \\
\text { network of } \\
\text { individual country } \\
\text { certificate tracking } \\
\text { systems. } \\
\text {-There are presently } \\
6 \text { individual country } \\
\text { certificate-based } \\
\text { tracking systems in } \\
\text { place (AT, DK, NL, } \\
\text { UK, IT, BE) } \\
\text { - These are } \\
\text { networked together } \\
\text { via RECS, although } \\
\text { some country rules } \\
\text { do not allow trading } \\
\text { between countries. }\end{array}$ & $\begin{array}{l}\text {-Generators } \\
\text { calculate } \\
\text { certificate } \\
\text { entitlement and } \\
\text { create electronic } \\
\text { certificates via } \\
\text { web-based registry } \\
\text { operated by ORER } \\
\text {-Any change in } \\
\text { ownership of } \\
\text { certificates is } \\
\text { recorded in ORER } \\
\text { registry } \\
\text {-Certificates are } \\
\text { retired/expired at } \\
\text { request of owner }\end{array}$ \\
\hline Location/Domain & $\begin{array}{l}\text { Texas/ERCOT Control } \\
\text { Area }\end{array}$ & $\begin{array}{l}\text { NEPOOL Control Area- } 6 \\
\text { New England States }\end{array}$ & Wisconsin & $\begin{array}{l}\text { PJM and PJM West with } \\
\text { possible expansion to } \\
\text { the Midwest }\end{array}$ & $\begin{array}{l}\text { Each country that } \\
\text { has a system that } \\
\text { controls RECs } \\
\text { issued to } \\
\text { generators in their } \\
\text { country. }\end{array}$ & Australia \\
\hline $\begin{array}{l}\text { Primary } \\
\text { Function of } \\
\text { System }\end{array}$ & $\begin{array}{l}\text { Verify utility and ESP } \\
\text { compliance with State } \\
\text { RPS. Secondary function } \\
\text { to verify green power } \\
\text { claims). }\end{array}$ & $\begin{array}{l}\text { Develop and issue } \\
\text { environmental disclosure } \\
\text { labels; Verify RPS and } \\
\text { GPS compliance where } \\
\text { applicable. }\end{array}$ & $\begin{array}{l}\text { Track and verify utility } \\
\text { compliance with State } \\
\text { RPS; facilitate trading } \\
\text { of RRCs among } \\
\text { electric providers. }\end{array}$ & $\begin{array}{l}\text { Develop and issue } \\
\text { environmental } \\
\text { disclosure labels; Verify } \\
\text { RPS compliance; } \\
\text { provide verification } \\
\text { function for market } \\
\text { participants dealing in } \\
\text { RE certificates. }\end{array}$ & $\begin{array}{l}\text { Verify RE } \\
\text { generation for in- } \\
\text { country greenhouse } \\
\text { gas requirements, } \\
\text { in-country RE } \\
\text { obligations, and } \\
\text { voluntary green } \\
\text { markets. * }\end{array}$ & $\begin{array}{l}\text { Verify compliance } \\
\text { with Federal RPS }\end{array}$ \\
\hline
\end{tabular}




\begin{tabular}{|c|c|c|c|c|c|c|}
\hline $\begin{array}{l}\text { System } \\
\text { Administrator }\end{array}$ & $\begin{array}{l}\text { ERCOT with some } \\
\text { shared responsibilities } \\
\text { with PUCT }\end{array}$ & $\begin{array}{l}\text { APX with some shared } \\
\text { responsibilities by NE } \\
\text { regulators }\end{array}$ & Clean Power Markets & $\begin{array}{l}\text { PJM or an outside } \\
\text { contractor, possibly with } \\
\text { some shared } \\
\text { responsibilities by } \\
\text { regulators }\end{array}$ & $\begin{array}{l}\text { Usually } \\
\text { governmental entity } \\
\text { in each country }\end{array}$ & ORER \\
\hline Source of Data & $\begin{array}{l}\text { Electronic transfer of } \\
\text { settlement quality meter } \\
\text { data }\end{array}$ & $\begin{array}{l}\text { Financial settlements } \\
\text { data from ISO's Market } \\
\text { Settlement System }\end{array}$ & $\begin{array}{l}\text { Electronic transfer of } \\
\text { settlement quality } \\
\text { meter data, manual } \\
\text { entry of meter data, } \\
\text { and self-reported }\end{array}$ & $\begin{array}{l}\text { Financial settlement } \\
\text { data from system } \\
\text { operator; possibly } \\
\text { eGRID or generator } \\
\text { reporting }\end{array}$ & $\begin{array}{l}\text { Electronic transfer } \\
\text { of meter data; }\end{array}$ & Self-reported \\
\hline $\begin{array}{l}\text { Participation in } \\
\text { System }\end{array}$ & $\begin{array}{l}\text { Mandatory for companies } \\
\text { that must meet RPS; } \\
\text { voluntary for other market } \\
\text { participants }\end{array}$ & $\begin{array}{l}\text { Mandatory for all } \\
\text { generators and LSEs; } \\
\text { voluntary for other market } \\
\text { participants }\end{array}$ & $\begin{array}{l}\text { RPS compliance } \\
\text { mandatory for all WI } \\
\text { electric providers; } \\
\text { RRC trading } \\
\text { participation voluntary }\end{array}$ & $\begin{array}{l}\text { Mandatory for all } \\
\text { generators and LSEs; } \\
\text { voluntary for other } \\
\text { market participants }\end{array}$ & $\begin{array}{l}\text { Varies- in general, } \\
\text { all countries have } \\
\text { mandatory } \\
\text { participation at } \\
\text { some level, except } \\
\text { for the Netherlands }\end{array}$ & $\begin{array}{l}\text { Mandatory for all } \\
\text { companies with a } \\
\text { renewable obligation; } \\
\text { voluntary for other } \\
\text { market participants }\end{array}$ \\
\hline Imports/Exports & Generally not applicable & $\begin{array}{l}\text { Unit-specific imports or } \\
\text { exports must be } \\
\text { physically delivered } \\
\text { to/from NEPOOL system. } \\
\text { System mix } \\
\text { imports/exports assigned } \\
\text { system or "residual" } \\
\text { average. }\end{array}$ & $\begin{array}{l}\text { Imports of renewable } \\
\text { energy allowed from } \\
\text { renewable generators } \\
\text { that have a wholesale } \\
\text { contract with a WI } \\
\text { electric provider }\end{array}$ & TBD & $\begin{array}{l}\text { About } 1 / 2 \text { of } \\
\text { countries allow } \\
\text { international trade } \\
\text { of } R E \text { certificates }\end{array}$ & Not applicable \\
\hline $\begin{array}{l}\text { Verification of } \\
\text { Generator } \\
\text { Attribute } \\
\text { Information }\end{array}$ & $\begin{array}{l}\text { Generators register and } \\
\text { become "certified" by the } \\
\text { PUCT }\end{array}$ & $\begin{array}{l}\text { Generator information } \\
\text { verified by state } \\
\text { regulators }\end{array}$ & $\begin{array}{l}\text { Generators register } \\
\text { and become } \\
\text { "certified" by } \\
\text { Wisconsin PSC, } \\
\text { including out-of-state } \\
\text { generators referenced } \\
\text { above }\end{array}$ & TBD & $\begin{array}{l}\text { In country system } \\
\text { operator }\end{array}$ & $\begin{array}{l}\text { ORER oversees } \\
\text { the accreditation, } \\
\text { verification and } \\
\text { spot auditing of } \\
\text { generators and } \\
\text { information } \\
\text { recorded in } \\
\text { registry }\end{array}$ \\
\hline $\begin{array}{l}\text { Maximum } \\
\text { lifespan of } \\
\text { certificates }\end{array}$ & Approx 3 years & $\begin{array}{l}\text { Up to } 1 \text { year; certificates } \\
\text { can be banked and used } \\
\text { within calendar year they } \\
\text { were generated. }\end{array}$ & $\begin{array}{l}\text { Current rules have no } \\
\text { expiration date for } \\
\text { RRCs }\end{array}$ & TBD & $\begin{array}{l}\text { Varies. Certificate } \\
\text { lifespan ranges } \\
\text { from } 2 \text { years to } \\
\text { unlimited amount of } \\
\text { time. }\end{array}$ & $\begin{array}{l}\text { Current rules have } \\
\text { no expiration date } \\
\text { for certificates }\end{array}$ \\
\hline Other Features & $\begin{array}{l}\text { Banking and borrowing } \\
\text { capability for RPS }\end{array}$ & $\begin{array}{l}\text { GIS organized in } \\
\text { quarterly trading periods. } \\
\text { System automates line } \\
\text { losses, pumped storage, } \\
\text { green tag transactions, } \\
\text { etc. }\end{array}$ & $\begin{array}{l}\text { "Bulletin board" } \\
\text { provided to facilitate } \\
\text { trading of RRCs }\end{array}$ & & & $\begin{array}{l}\text {-Stiff penalties for } \\
\text { fraudulent creation } \\
\text { of certificates; } \\
\text {-Interfaces with a } \\
\text { privately operated } \\
\text { market-trading } \\
\text { platform. }\end{array}$ \\
\hline
\end{tabular}

* Although the European RECS at this time tracks only renewable certificates, the EU just adopted a disclosure requirement that will force Europeans to consider whether to track all generation. Member States will each decide for themselves whether to use contract tracking or certificate tracking, and whether the tracking system will be parallel to but separate from RECS, or whether RECS will be redesigned to accommodate all generation. 


\section{Major Issues and Challenges}

Based on the number of tracking systems in operation to date, several issues can be identified that relate to the design and functionality of any tracking system. Decisions must be made about the following issues:

- Should the system track renewable generation only, or all generation? Because an allgeneration tracking system tracks RECs, as well as the generation attributes of nonrenewable generators, it is considered a REC tracking system for the purpose of this discussion.

- What should be the geographic scope of the tracking system? Should it serve a single state or a multi-state region?

- Who will develop the tracking system and where should it be housed once developed?

- To what extent should tracking systems be coordinated with others? This decision affects imports and exports of RECs, and acceptability and credibility of RECs created in one domain but used in another.

- Should the system track certificates only, or track bundled renewable energy transactions as well?

- Should the system track individual attributes that have been disaggregated from the REC, and if so, how?

- How should the system ensure reliability and security of data? Decisions about data acquisition and management affect data sources and quality, and access to data.

- Should the tracking system be limited to issuing, tracking and retiring certificates, or should it also be designed to include market-making or trading functions?

- Who will pay for the development and ongoing operation of the tracking system, and how will those costs be recovered?

- What process should be used in the development and design of the tracking system? To what extent will the process solicit and incorporate stakeholder input?

Each of these issues poses challenges, and of course the design options each have pros and cons. Each of these issues is considered in turn below.

\section{RECs-Only or All Generation Tracking Systems}

One of the most fundamental design decisions is whether or not the system should track renewable generation only, or all generation. With regard to functional capabilities, one advantage of the all-generation model is its ability to meet many regulatory verification needs. Because the system tracks all generation attributes, it has a complete picture of the disposition of all electricity attributes in its domain.

As an example of an all-generation tracking system, the NEPOOL GIS system is able to produce environmental disclosure labels for all utilities and all electricity products sold within its system. 
Because it also tracks emissions information from generating units, it has the ability to summarize the emissions profiles of every retail provider in the system, as well as verify whether the companies have purchased enough renewables to meet state RPS targets. Although these are the three primary regulatory uses of the NEPOOL GIS data, the data could be used in a variety of other ways that perhaps have not yet been envisioned. An all-generation tracking system also prevents problems like double counting or double selling because it is a closed loop system where every MWh is accounted for.

REC-only tracking systems collect generation information from renewable generators only, so the information contained in REC-only databases is a subset of the entire power pool, or system. A REC-only tracking system can verify RPS compliance, renewable product claims and the renewable portion of an environmental disclosure label, but it typically cannot verify claims or make any statements about the quantity or type of generation from non-renewable generating units. Therefore, these systems are limited in providing other services, such as producing environmental disclosure labels for the non-renewable portion of retail products, or producing information about emissions for a utility portfolio or the entire system.

\section{Tradeoffs of Increased Functionality vs. Increased Flexibility}

Although all-generation tracking systems may offer more functionality than REC-only tracking systems, there are trade-offs inherent in this increased functionality caused by the interaction between state policy requirements and the realities of energy markets. For example, if the system is being used to produce environmental disclosure labels to meet a state requirement, all load-serving entities (LSEs) in the system should have the same number of generation attributes as MWh served. ${ }^{5}$

\section{The Problem of Tracking in Spot Markets}

This is a simple proposition if the LSE purchases its energy through bilateral contracts, because such contracts show a clear path of ownership from seller to buyer. Only a portion of the electricity market is transacted through bilateral contracts, however; the remainder is transacted in spot markets. For electricity that is bought and sold in a spot market, there is no clear path of ownership between a generator and a LSE. Generators sell their power into electricity markets, and buyers buy their power out of these markets, but there is no way for buyers to specify that they are buying from a particular generating unit. They are simply buying electricity from the pool.

In this example, the spot market will likely contain generation attributes from a variety of generating units, everything from wind plants to coal plants. Designers of all-generation tracking systems must therefore decide how to assign attributes (or certificates) to buyers of the spot electricity, such that all LSEs have the same number of certificates as MWh served. ${ }^{6}$

\footnotetext{
${ }^{5}$ The reason for this is that in order to report their electricity portfolio to consumers, LSEs need to know what kind of generation was purchased to meet their load. The sum of all the generation attributes can be used to create the environmental disclosure label.

${ }^{6}$ REC-only tracking systems do not have to deal with the problem of spot market purchases, because they are only dealing with a portion of electricity sales. LSEs do not need certificates for all MWh sold, only for the renewable energy claimed.
} 
REC-only tracking systems do not have to deal with the problem of spot market purchases because most renewable energy is purchased through bilateral contracts. Further, REC-only tracking systems do not need to match attributes to all MWh sold in the system because they track only a small portion of all generation attributes.

The NEPOOL GIS handles the problem of spot market purchases through a fixed "settlement," whereby all generation certificates in the system are accounted for and assigned to LSEs on a given date. The generation certificates assigned are created for this purpose at the close of each reporting period by the GIS administrator, based on the aggregate characteristics of outstanding certificates not associated with MWh. What this means practically for renewable generators is that if they have not sold their attributes to a LSE or put them in a reserve account by the settlement date, their certificates are taken out of their account and divided up among retail LSEs.

There are two disadvantages associated with a fixed settlement design. First, certificates are taken from the generators and assigned to other parties without payment for any value they might have. Some argue that this policy ignores the property rights of generators by expropriating their property (the unsold certificates). The designers of the NEPOOL GIS partially alleviated this problem by allowing generators to set aside their certificates in a reserve account until the end of the calendar year, giving them extra time to find a buyer. ${ }^{7}$ However, if the generator still has not found a buyer by the end of the year when annual settlement occurs, the same loss of certificates and potential value still exists.

The second disadvantage of a fixed settlement is that it limits the potential lifespan of certificates. With a fixed settlement date, those certificates issued closer to the settlement date have less time to be sold. For example, if the fixed settlement date is December 31, certificates issued on January 1 and December 1 have very different life spans (12 months versus one month respectively); those issued later in the year may only have a few days or months to be sold before they expire. The deadline imposed by the fixed settlement design is pretty much inherent in the approach and cannot be avoided, but a fixed settlement that occurs annually or longer is much less onerous than one imposed every quarter.

Since there is only one operating example of an all-generation tracking system, it is difficult to separate the local circumstances in New England that precipitated the design of the NEPOOL GIS from characteristics of all-generation tracking systems writ large. Although the NEPOOL GIS opted to address the issue of spot market purchases through a fixed settlement, it is conceivable that other all-generation tracking systems could be designed with a different solution, eliminating the problem described above. Discussions in the PJM GATS Work Group, for example, have suggested alternatives, but none has yet achieved consensus.

\section{Effect on Costs}

A final point on the choice between a REC-only and an all-generation tracking system relates to cost recovery. It would be logical to recover the costs of an all-generation tracking system

\footnotetext{
${ }^{7}$ Previously, generators only had one quarter to find a buyer because the NEPOOL GIS has a quarterly settlement period.
} 
through fees charged to all market participants (or all electricity sales). A REC-only tracking system, on the other hand, might be more likely to collect fees only on renewable energy transactions, although there is nothing that inherently limits the system from charging the cost to all electricity sales. The per-MWh cost of a REC-only system could thus be significantly higher than that for an all-generation system, which would add to the incremental cost already experienced by most renewable electricity. Fee structures are discussed in greater detail below.

\section{Geographic Scope of Tracking Systems}

Worldwide, there are examples of state, regional and national REC tracking systems. A single national REC tracking system in the US seems unlikely in the near future, but multi-state and individual state systems currently operate. ${ }^{8}$ Larger or multi-state tracking systems offer several important advantages over single state systems, in terms of operation, but they pose challenges in the development process.

\section{Benefits of Large Area Tracking}

The primary benefits of a large geographic scope relate to competition, market liquidity, fungibility of certificates, minimization of seams issues, and more cost-effective development and operation. Larger regions, by virtue of the larger market, include more buyers and sellers, which promotes price competition. RECs created in a single system are generally recognized within the geographic confines of that system (though not necessarily accepted for compliance with policy in each jurisdiction), but they may or may not be recognized outside the geographic scope of the system. Liquidity and fungibility will naturally increase in a broader geographic area. REC imports and exports between tracking systems (seams), or between a geographic area with a tracking system and one without, are decreased or eliminated as the geographic scope expands. Finally, the start-up costs of the system and the cost of ongoing operation are spread across more users and jurisdictions as the geographic scope grows, increasing economies of scale.

Another benefit of multi-state scope is that it is easier to avoid double counting in the disclosure of each state's electricity system mix. The sale of RECs separate from electricity can make it difficult to determine an accurate state resource profile unless RECs sold outside the state are subtracted from the in-state renewable base. Having a regional tracking system ensures that these adjustments are made accurately and automatically. In general, the broadest possible geographic scope for a REC-tracking system is preferred because of these benefits. However, along with these benefits come challenges.

\footnotetext{
${ }^{8}$ There are also proposals for tracking systems based on specific technologies (solar photovoltaic generators), generator ownership (publicly owned utilities), and free agency or affiliation (registries for generators located in non-contiguous areas not served by a tracking system that want to increase credibility in their RECs). Because state leadership is important to policy and regulatory acceptance, this Design Guide focuses on political or functional geographic domains.
} 


\section{Challenges of Large Area Tracking}

The primary challenge with multi-state collaboration is that there is usually an increase in the number of interested stakeholders and policy goals. Although multi-state collaboration does not require participating states to adopt the same standards or definitions for an RPS, for example, a greater number of states or jurisdictions involved complicates every step of the decision-making process. ${ }^{9}$ This factor can make the process drag on with frustrating or unsatisfactory results.

With multi-jurisdictional scope, there are also issues of legislative or regulatory mandates that affect cost allocations and timing of system development. Frequently, within a region there will be some states that want a tracking system because of policy mandates, and others that have no mandates. How costs are allocated can be complicated when participants have different budgets, or are simply unwilling or unable to pay for something they do not feel their state will use. Similarly, some jurisdictions may have legislatively imposed deadlines for when a tracking system must be in place. Others in the region may not be able to start working on creating a tracking system until legislation is enacted. In summary, although regional tracking systems may be ideal, it usually takes a confluence of circumstances to create the right environment to launch a successful regional REC tracking system.

The next section on Institutional Issues examines additional aspects of multi-state systems.

\section{Institutional Issues}

As noted above, the level of complexity related to institutional issues increases between a singlestate tracking system and a multi-state tracking system. Because the institutional issues are more complex for a multi-state or regional tracking system compared to a single-state system, this discussion focuses on the institutional issues of a multi-state REC tracking entity, although many of these same issues apply to developing a single-state tracking system.

There are two critical stages for REC tracking systems, both of which require a sound institutional home: the design phase and the operation phase. It is important to note that the institutional leadership for each of these phases need not be the same, although there should be a plan to facilitate a smooth transition if they are different. There are several possible institutional options for each phase, and the pros and cons of each are summarized in Table 2.

\section{Issues Relating to System Development}

Providing an effective institutional home for managing the development of a regional REC tracking system is vitally important. Establishing agreement on the purpose, capabilities and design of the tracking system can be challenging, particularly when states have significantly different regulatory requirements. Adequate institutional support to bring parties together, facilitate discussion of sensitive issues, and manage conflict resolution is critical to the success of establishing a sound framework for a regional REC tracking system.

\footnotetext{
${ }^{9}$ While tracking systems are accommodating and generally do not require consistency among participating states' policies, some differences may require compromise, slowing the planning process.
} 


\section{Issues Related to System Operation}

Similarly, the tracking system should have a sound operational home with appropriate policies and funding to settle disputes, respond to changes needed in the system, adequately manage the data, maintain security, and fulfill reporting and other participant needs in a timely manner.

Table 2. Pros and Cons of Institutional Options for REC Systems

\begin{tabular}{|c|c|c|}
\hline Institutional Leader & Pros & Cons \\
\hline System operator & $\begin{array}{l}\text { Has all financial settlements } \\
\text { data that is the basis for } \\
\text { issuing certificates. Has } \\
\text { excellent technical information } \\
\text { and experience necessary to } \\
\text { inform design decisions. Likely } \\
\text { to be involved in data } \\
\text { acquisition for system. Is an } \\
\text { important player to have } \\
\text { involved at the beginning. }\end{array}$ & $\begin{array}{l}\text { May have limited } \\
\text { understanding or experience } \\
\text { with REC-only transactions. } \\
\text { Depending on experience, } \\
\text { may be taking system operator } \\
\text { into significantly new role. }\end{array}$ \\
\hline $\begin{array}{l}\text { State PUC or state regulatory } \\
\text { body }\end{array}$ & $\begin{array}{l}\text { Important stakeholder. May } \\
\text { have regulatory incentive to } \\
\text { meet deadlines and keep } \\
\text { process moving successfully. } \\
\text { Easier for one state regulatory } \\
\text { body to get other state } \\
\text { regulatory bodies involved. }\end{array}$ & $\begin{array}{l}\text { State may not have the budget } \\
\text { or mandate to create regional } \\
\text { system. May be difficult to } \\
\text { compromise on function or } \\
\text { purpose of system because of } \\
\text { state mandate. May be } \\
\text { politically sensitive for one } \\
\text { state in region to have } \\
\text { preeminent leadership role. }\end{array}$ \\
\hline $\begin{array}{l}\text { Regional regulatory or } \\
\text { governmental body, such as } \\
\text { regional air quality } \\
\text { collaborative (e.g. NESCAUM, } \\
\text { WRAP) or a regional } \\
\text { governors' association (e.g., } \\
\text { WGA ) }\end{array}$ & $\begin{array}{l}\text { Has experience working on } \\
\text { regional issues, may already } \\
\text { have regional decision-making } \\
\text { protocol in place. All parties } \\
\text { considered equal partners } \\
\text { (more difficult for one state to } \\
\text { dominate). Includes } \\
\text { representatives from all states, } \\
\text { even if one state does not } \\
\text { have a regulatory mandate. }\end{array}$ & $\begin{array}{l}\text { Depending on organization, } \\
\text { may have a narrow focus on } \\
\text { air quality issues or other } \\
\text { policy mandates as opposed } \\
\text { to broader markets. May take } \\
\text { longer to make decisions } \\
\text { because process is more } \\
\text { politicized. }\end{array}$ \\
\hline $\begin{array}{l}\text { Collaborative of regional } \\
\text { market participants and others }\end{array}$ & $\begin{array}{l}\text { Has incentive to create system } \\
\text { that is good for voluntary and } \\
\text { mandatory renewable } \\
\text { markets. Has the most } \\
\text { experience with market needs } \\
\text { and tracking system design } \\
\text { issues from other states }\end{array}$ & $\begin{array}{l}\text { May not have a designated } \\
\text { budget or staff to keep } \\
\text { process moving successfully. } \\
\text { Depending on leadership, may } \\
\text { have stake in outcome that } \\
\text { drives the process. May lack } \\
\text { essential participation and } \\
\text { buy-in from state regulators. } \\
\text { May lack an enforcement } \\
\text { mechanism without the strong } \\
\text { participation of regulators. } \\
\text { Would most likely hand off } \\
\text { leadership during operation } \\
\text { phase. }\end{array}$ \\
\hline $\begin{array}{l}\text { Contractor- company paid to } \\
\text { facilitate a process, handle } \\
\text { administrative needs and/or }\end{array}$ & $\begin{array}{l}\text { Impartial, no stake in one } \\
\text { decision over another. Can be } \\
\text { effective at helping group }\end{array}$ & $\begin{array}{l}\text { May be difficult for states and } \\
\text { other stakeholders to raise } \\
\text { money at the beginning of the }\end{array}$ \\
\hline
\end{tabular}




\begin{tabular}{|l|l|l|}
\hline $\begin{array}{l}\text { provide operational home to } \\
\text { the system (This option still } \\
\text { requires some oversight from } \\
\text { one the previous groups.) }\end{array}$ & reach consensus. & $\begin{array}{l}\text { process. Will add time to the } \\
\text { process to issue an RFP for a } \\
\text { contractor, and will take time } \\
\text { for the contractor to set up the } \\
\text { "institutional" part of the } \\
\text { system. }\end{array}$ \\
\hline
\end{tabular}

\section{REC Imports and Exports and Tracking Systems Coordination}

Unless a national REC tracking system is instituted, it is likely that there will be challenges related to the coordination of regional and state REC tracking systems with each other. Among these is the challenge of balancing the benefits of large, efficient regional REC markets with the local interest in siting new renewables generation in-state.

Currently, policies allowing imports and exports of RECs into or out of the existing tracking systems are extremely limited. ${ }^{10}$ To the extent that inter-state and inter-regional REC trade is not captured by a legitimate tracking system, there are opportunities for double selling to occur when transactions go unaccounted.

\section{Coordination of Tracking Systems}

There is one effort underway to rectify some of these seams issues by establishing a North American standard-setting body that would facilitate the agreements needed to create a network of REC tracking systems. This organization, known as the North American Association of Issuing Bodies (NAAIB) will facilitate the development of basic rules and minimum standards for certificate accounting in Canada, Mexico and the United States. These rules and standards will be conceptual (as opposed to prescriptive) and are meant to preserve transferability and accuracy of information. They will not govern how a specific tracking system operates or what mechanism a tracking system uses to fulfill the minimum obligations necessary to participate in the North American network. As envisioned, the rules and standards for coordination, known as the "Basic Commitment," will be discussed and modified through the NAAIB forum of affiliated tracking systems. ${ }^{11}$

One potential challenge related to coordination between REC tracking systems is to avoid overlapping or duplicative tracking systems in any one geographic area. Overlapping or uncoordinated adjacent systems may result in a single generator registering its output with more than one REC tracking system, essentially creating two certificates for every MWh of generation. For this reason is it crucial that REC tracking systems require that generators fully opt-in, meaning that all output from a given generation facility is tracked by one and only one tracking regime. A national generator registration would keep track of which accounting system a specific generator is registered with and thus prevent a generator from signing up with more than one accounting system. The NAAIB described is planning to host such a registry.

\footnotetext{
${ }^{10}$ For a summary of import and export policies, see Table 1.

11 The most recent draft of the NAAIB Basic Commitment can be found at http://www.resourcesolutions.org/Libraryindex.htm.
} 


\section{Imports and Exports}

Related to the above issues of coordination among states and REC tracking entities is how to handle imports and exports. ${ }^{12}$ There are many layers to this issue, both technical and political. First is the technical challenge associated with developing standards and protocols for transferring information between two tracking systems, or between a tracking system and a neighboring control area. Issues such as security, data compatibility, and validity of information are all concerns. Generally speaking, existing tracking systems have strict requirements for issuing certificates based on revenue-quality meter data that is closely monitored by the RTO, ISO or regulatory body. Responsible parties want to ensure that any imported RECs meet at least the same minimum standards.

A second technical issue is related to the compatibility of the imported or exported REC itself. A REC issued by one tracking system might not be compatible with a REC issued by another tracking system. For example, one tracking system may allow disaggregated RECs (a REC with one or more attributes missing) to commingle with "whole" or fully-aggregated RECs, while another system only allows whole RECs. Therefore, ensuring that RECs are comparable may be a challenge.

There are also political challenges associated with importing or exporting RECs. Tracking system import/export capabilities may reflect a state's desire to exclude outside generation from state RPS or other public programs, in the belief that importation will create unwanted competition to in-state renewables. Also, if one state offers relatively strong support for renewables (an RPS or financial incentives), it may not want the benefits of those policies (investment, jobs and income, or air quality improvement) to flow outside the state. One way to discourage this is to restrict REC imports.

\section{Distinguishing between Public Policy and Tracking System Functionality}

The question of whether or not RECs should be allowed to be imported into a tracking system often has an underlying assumption that acceptance into the REC tracking system will automatically make the imported RECs eligible for any regulatory programs in that domain. This is not the case, as eligibility is determined solely by individual state policies. Stakeholders should not confuse a technical issue of tracking system capability to import or export RECs with state policy-makers' prerogative to decide REC eligibility for their own state programs. Nevertheless, the temptation to use the tracking system to limit imports (by constraining functionality) is great because it is difficult to craft a policy that restricts interstate trade of RECs without making the state vulnerable to legal challenges. ${ }^{13}$

The disadvantage of imbedding a restrictive import policy in the design of the tracking system is that it hinders REC trading, frustrates the broader renewable energy market and generally limits the market opportunities of renewable generators. It may also force legitimate inter-regional

\footnotetext{
${ }^{12}$ This topic has been written on extensively by Grace and Wiser in their paper, "Transacting Generation Attributes Across Market Boundaries." (2002)

${ }^{13}$ Limiting eligibility to RECs generated within the state is likely to violate the Commerce Clause of the U.S. Constitution because it discriminates against out-of-state goods. See Nancy Rader and Scott Hempling, The Renewables Portfolio Standard: A Practical Guide. The National Association of Regulatory Utility Commissioners, 2001.
} 
trading to occur outside the tracking system, which could reduce consumer confidence in the integrity of RECs.

On the other hand, it could be argued that restricting REC imports could increase consumer confidence because the restriction would ensure that REC or green power purchases would support local or regional environmental benefits.

Clearly, import and export capabilities present a tradeoff between wider markets for RECs and supporting local resources. There is more to be said about this in the next section.

\section{Bundling Energy and Attributes}

Another issue related to imports and exports is whether or not the RECs in the tracking system are bundled with energy. The requirement to track RECs and energy together is usually a result of a policy requirement, and it can significantly affect tracking system design.

This type of requirement may stem from a desire for local benefits rather than a specific intent to restrict REC trading. Policy-makers may want proof that imported renewable energy is displacing local non-renewable generation, and therefore has the real effect of cleaning up the electricity system. Some states have in fact required that imported RECs be accompanied by an energy delivery, which has a similar effect to a bundling requirement. ${ }^{14}$

Although it may seem logical and necessary to require imported RECs to be accompanied by imported electricity, it is hard to implement in any meaningful way because of the realities of energy markets. First, electricity flow in most parts of the U.S. is generally regional in scope and is not tracked to the state border. While it may be technically possible to ensure energy delivery from outside the power pool into the state or at least the region, this is neither a practical nor a meaningful policy. It is not practical because of the expense involved and the fact that electricity is not managed in this way, and not very meaningful because there are many ways for a company to work around such a requirement, for example through swap transactions and other legitimate wholesale market tools.

Second, requiring energy and attributes to remain bundled restricts the marketing opportunities for renewable generators. One of the major benefits of RECs is that energy and attributes are decoupled, allowing maximum flexibility and increased market opportunities.

Third, the primary reason that a state would require bundling relates to generator eligibility for a state RPS or other program. As mentioned above, attempts to restrict out-of-state participation in an RPS or other program can run afoul of the U.S. Constitution's Commerce Clause. Rader and

\footnotetext{
${ }^{14}$ For example, to satisfy their RPS requirements, Texas and Nevada require that out-of-state renewable generation be delivered in-state via a dedicated transmission line. New Mexico and Arizona require in-state generation of renewable energy for their RPSs, except that Arizona will accept out-of-state solar if the power reaches Arizona customers. California requires that out-of-state generators deliver electricity into the state. Whether RECs will be allowed to trade separately from electricity is under discussion by the PUC. In a non-RPS example, New York allows unbundling of attributes only for energy sold into the New York ISO spot market, effectively an in-state requirement. Other transactions remain bundled.
} 
Hempling concluded that in-state delivery requirements, in-state sales requirements, geographic limitations (based on state boundaries or physical distance) all were discriminatory against other states. $^{15}$ Their analysis indicated that the best way to avoid Commerce Clause challenges is to base eligibility on benefits accrued to the state. This type of test can be performed without a bundling requirement, and without the need to imbed a policy decision into the design of the certificate tracking system.

If a state requires energy and attributes to remain bundled, the main challenge is how to design a tracking system that accommodates this requirement. Tracking systems that are affiliated with an RTO or ISO would have a much easier time fulfilling this requirement than a tracking system that deals exclusively in RECs or generation attributes. In the latter case, it is necessary to design the system to track and substantiate not only generation data but also energy contracts.

\section{Disaggregation of Attributes}

RECs are usually defined as the set of generation attributes unbundled from electricity. Consistent with multiple markets for RECs, the set of attributes embodied in a REC (such as various emission reductions) can be further disaggregated and sold separately. For example, the NOx emissions reductions might be used to earn NOx emission allowances in states that support this, or $\mathrm{CO} 2$ emission reductions might be claimed in voluntary carbon registries and sold either today in voluntary greenhouse gas markets or later if mandatory greenhouse gas targets are adopted.

The motivation to sell individual attributes into different markets arises from the potential for a REC owner to take advantage of multiple revenue streams. Whether the revenue from multiple markets would exceed the revenue from a fully aggregated REC is unclear because there has been no real experience. What is certain is that some owners of RECs and some policy advocates have staked out the position that one should be able to separate the components elements of a REC and sell them separately.

\section{The Disaggregation Controversy}

Disaggregation is controversial because if a generator sells one or more of its emissions reductions into environmental markets, and tries to sell the remaining attributes (say, just the wind attribute) for compliance with an RPS or to support a voluntary green marketing claim, it would constitute a partial double sale. ${ }^{16}$ This disaggregation would be hard, perhaps impossible, to explain to consumers in retail markets. For example, just what is a consumer getting with a wind REC if its emissions benefits have been eliminated? Disaggregation could undermine the credibility of retail markets for RECs. ${ }^{17}$

\footnotetext{
${ }^{15}$ See Rader and Hempling, op. cit., pp. A-1 - A-9.. We are not aware of any legal challenges to in-state requirements, however.

${ }^{16}$ For more detail on double sales and similar issues, see J. Hamrin and M. Wingate, Regulator's Handbook on Tradable Renewable Certificates. San Francisco: Center for Resource Solutions, 2003.

${ }^{17}$ In its Consensus Credit Trading Opportunities and Guidelines (2001), the NWCC had this to say about disaggregation. "Attribute Disaggregation: Laws, regulations and markets should recognize that environmental attributes can be disaggregated from each other where appropriate and consistent with consumer protection guidelines and the healthy development of markets. [italics in original] Disaggregated environmental attributes
} 
For compliance with the Texas RPS, only whole RECs are valid-retail load serving entities are required to own all the REC attributes. Other states may make different policy decisions about this. For voluntary markets, acceptable RECs sales may come under the jurisdiction of the Federal Trade Commission and state attorneys general, which oversee consumer fraud and would investigate marketing claims about green power and REC sales. ${ }^{18}$

\section{Should Tracking Systems Track Disaggregated RECs?}

Regardless of where one stands on this controversial policy issue, it raises a question about whether REC tracking systems should be designed to accommodate - that is, to track - the sale of disaggregated attributes? Most observers would agree that systems designed to track each individual attribute would be costly, complex and unwieldy. Alternatively, tracking systems could be designed to track only whole RECs. In that approach, if one or more attributes were disaggregated and sold separately, the REC might be rendered ineligible for further trading in compliance (RPS) markets, and would be ineligible for voluntary green marketing according to current certification standards. ${ }^{19}$ The remaining attributes could be further disaggregated for environmental markets and sold wherever they might find value.

The problem is, how would a system administrator know that a REC has been disaggregated? This suggests a third approach, one in which tracking system operating rules would require that REC owners report the disaggregated sales of any individual attributes. The tracking system would then be designed to flag RECs that have been disaggregated. That way, buyers would at least be aware that they are not getting the whole REC, and could investigate further whether or not the REC meets their needs. This third approach still relies on voluntary disclosure by REC owners, but increasingly sophisticated wholesale buyers should determine in contract negotiations whether they are getting a whole REC, and thus contracting practices may discipline REC owners to make the appropriate disclosures to tracking systems.

\section{Data Acquisition}

REC tracking systems are entirely dependent on data acquisition. There are generally four sources of generation data used: ISOs or RTOs, state Public Utility Commissions, utilities or local distribution companies, and self-reported generation data. Tracking systems that are set up as an adjunct to the ISO or RTO have far fewer challenges related to data acquisition than tracking systems set up in the absence of an ISO or RTO. In the latter case, the tracking system may be reliant on data from a variety of sources, which could result in greater expense, data inconsistencies and aberrations, and other technical complications. In this environment, a single-

might best be suited for environmental compliance programs. Aggregated environmental attributes might best be suited for consumer retail markets." Also, "Thorough Disclosure: Full disclosure is important to the development and operation of credit trading markets. Disclosure should be easy to understand, standardized, compatible across jurisdictions and apply across-the-board to all electricity providers. Environmental attributes sold must be disclosed. However, some believe that disclosure may not be sufficient to clarify claims about green power products that do not contain all of their environmental attributes."

${ }^{18}$ See National Association of Attorneys General, Environmental Marketing Guidelines for Electricity, 1999, and Memorandum from NAAG Environmental Marketing Subcommittee, January 10, 2000.

${ }^{19}$ See Green-e, Green-e National Tradable Renewable Certificate (TRC) Standards, no date. 
state tracking system is much easier to design and implement than a multi-state or regional system.

\section{Market-Making Responsibility}

Generally, REC tracking systems in operation today are independent from the RECs market. They perform primarily an accounting and verification function, and leave trading and market making to parties with a motivation to buy and sell. Some tracking systems have a bulletin board or place where buyers and sellers can advertise RECs for sale, but it is then up to private parties to negotiate the contracts and financial terms of the deal outside of the tracking system. Once the trade has been executed, the system is able to record the transaction, but there is no instance where a tracking system tracks the transaction price or other financial information along with the disposition of the REC.

\section{Advantages to Including Market-Making Responsibilities}

There are at least a couple reasons why it might be desirable for a tracking system also to facilitate transactions. First, REC markets are now immature and dispersed. Creating and operating a REC exchange in tandem with the tracking system could facilitate trading, decrease transaction costs for market participants, and generally help develop markets. Second, centralizing markets would encourage liquidity and price transparency. For example, the administrator could create and report price indices that would make it easier for regulators to monitor the cost of compliance with mandatory programs. Price indices would also support competition as generators would have a better idea of the price they have to beat.

\section{Disadvantages to Including Market-Making Responsibilities}

On the other hand, there are several reasons not to add a market-making function to the tracking function. Precisely because today's market is immature and dispersed, it could be argued that it is premature to decide that entrepreneurs will not respond when there is a clearer need. A number of private brokers are already active in bringing buyers and sellers together. Further, marrying the accounting function with a market-making function would be undesirable if doing so effectively grants the system administrator a monopoly. There may also be concerns about the independence and credibility of the tracking system if it has an interest in the market. Depending on how the market-making function is compensated, it might have an incentive to promote excessive trading or churn.

\section{Costs and Fees}

The institutional home for the development process and for the operation of the REC tracking system is often determined by who is paying. This fact can lead to unequal participation and involvement in the stakeholder process, and ultimately may give a more prominent decisionmaking role to some organizations. Although in the short term this can lead to the more rapid deployment of a tracking system, in the long run, it is likely to lead to the deployment of tracking systems that have limited functionality and may not be compatible with other regional tracking systems. For this reason, the most successful processes involve adequate funding for the administrative, facilitation, and managerial work provided by the institutional home, and that is 
paid for by as broad a variety of stakeholders as possible. The NEPOOL GIS is a good example of a successful collaborative process that was adequately funded.

The three main costs of a REC tracking system are: (1) administrative costs of the design and development phases, (2) costs related to developing an RFP, hiring a contractor, and creating the tracking software, and (3) ongoing operation costs of running the REC tracking system. These cost centers could be paid for through a surcharge on every certificate issued or on every certificate transaction, annual user registration fees, or public or private grants. Costs could also be recovered via one of the tariffs or schedules already approved by FERC for the power pool or ISO. Depending on the mechanism, the money could be collected up front and paid out as needed, or borrowed for up-front expenses and amortized through surcharges and user fees once the system is operational.

The costs of developing a REC tracking system can vary depending on the complexity of the system and the design (new system vs. one similar to an existing system). If all generation is included, costs charged per transaction may be lower because costs are spread over a greater volume of certificates or more participants. With a REC-only system, there may be equity issues with recovering system costs from all ratepayers or all market participants if the REC system only benefits a few market participants. A summary of the administrative costs of tracking systems designed to satisfy RPS compliance is shown in Table 3.

\section{Table 3. Estimates Costs of Certificate Tracking Systems}

\begin{tabular}{|c|c|c|c|}
\hline Name & Core Characteristics & Start-up Costs & Operational Costs \\
\hline $\begin{array}{l}\text { US: New England } \\
\text { Generation } \\
\text { Information System }\end{array}$ & $\begin{array}{l}\text { - Tracks all generation in } 6 \\
\text { state region } \\
\text { - Mandatory participation by } \\
\text { all generation units and } \\
\text { electricity suppliers } \\
\text { - Relatively sophisticated } \\
\text { system }\end{array}$ & $\begin{array}{l}\$ 200,000 \\
\text { Does not reflect } \\
\text { full cost of } \\
\text { development. A } \\
\text { significant share } \\
\text { is recovered in } \\
\text { transaction fees. }\end{array}$ & $\begin{array}{l}\text { Between } \$ 900,000-\$ 2.4 \mathrm{M} \text { per year } \\
\text { collected through transaction fees } \\
\text { levied on retail electricity suppliers } \\
\text { for load served. } \\
\text { The high operational costs reflect } \\
\text { the recovery of some system } \\
\text { development costs. Transaction } \\
\text { fees start higher and decline, as } \\
\text { shown for the first five years. } \\
\text { year } 1: \$ 0.0176 / \mathrm{MWh} \\
\text { year } 2: \$ 0.0173 / \mathrm{MWh} \\
\text { year } 3: \$ 0.0123 / \mathrm{MWh} \\
\text { year } 4: \$ 0.0098 / \mathrm{MWh} \\
\text { year } 5: \$ 0.0074 / \mathrm{MWh}\end{array}$ \\
\hline $\begin{array}{l}\text { US: Wisconsin } \\
\text { Renewable } \\
\text { Resource Credit } \\
\text { System }\end{array}$ & $\begin{array}{l}\text { - Tracks only renewable } \\
\text { energy purchased in excess } \\
\text { of WI utility requirement } \\
\text { - Only electricity suppliers } \\
\text { participate } \\
\text { - Simple accounting system }\end{array}$ & $\$ 50,000$ & $\begin{array}{l}\text { Approximately } \$ 60,000 / \text { year is } \\
\text { collected through a cents/MWh fee } \\
\text { allocated to the electric providers } \\
\text { based on the MWh of renewables } \\
\text { each provider needs to deliver to } \\
\text { meet the State's RPS requirement } \\
\text { in any particular year. }\end{array}$ \\
\hline $\begin{array}{l}\text { US: ERCOT } \\
\text { Renewable Energy } \\
\text { Credits System }\end{array}$ & $\begin{array}{l}\text { - Tracks only renewable } \\
\text { generation in TX that is } \\
\text { eligible for the RPS } \\
\text { - Voluntary participation by }\end{array}$ & $\$ 500,000^{*}$ & $\begin{array}{l}\text { Approximately } \$ 70,000 / \text { year is } \\
\text { collected for annual } \\
\text { program operations through a } \\
\text { per MWh fee assessed to all load- }\end{array}$ \\
\hline
\end{tabular}

${ }^{20}$ The actual amount of the fee varies each year based on the RPS requirement. 


\begin{tabular}{|c|c|c|c|}
\hline & $\begin{array}{l}\text { generators, mandatory } \\
\text { participation by companies } \\
\text { with RPS obligation } \\
\text { - Simple accounting system }\end{array}$ & & $\begin{array}{l}\text { serving entities in the Texas } \\
\text { ERCOT system. }\end{array}$ \\
\hline Netherlands: & $\begin{array}{l}\text { - Tracks only renewable } \\
\text { generation sold into the } \\
\text { Netherlands } \\
\text { - Generators and electricity } \\
\text { suppliers can participate } \\
\text { - Simple accounting system }\end{array}$ & $\begin{array}{l}\text { Initial costs were } \\
\text { amortized and } \\
\text { paid for through } \\
\text { the collection of } \\
\text { ongoing fees }\end{array}$ & $\begin{array}{l}\text { Approximately } € 250,000 / \text { year is } \\
\text { collected in annual registration fees } \\
\text { and } € 2.4 \mathrm{M}(\$ 3.0 \mathrm{M}) \text { in annual } \\
\text { transaction fees. } \\
\text { Annual Registration Fees: } \\
\text { Trader/Aggregator } € 2,500(\$ 3,125) \\
\text { Generators } € 25(\$ 31.25) \\
\text { Transaction Fees: } \\
\text { Issue certificates } € 0.10(\$ 0.125) \\
\text { Transfer certificates } € 0.02(\$ 0.025) \\
\text { Redeem certificates } € 0.10(\$ 0.125) \\
\text { Import certificates } € 0.02(\$ 0.025) \\
\text { Conversion as of } 1 / 28 / 04, € 1= \\
\$ 1.25\end{array}$ \\
\hline
\end{tabular}

* We do not know what the actual start-up costs were for the Texas tracking system. This is an independent estimate to design tracking system with similar features.

\section{Process Issues and Challenges}

A multi-stakeholder process to develop and design a certificate-based tracking system can be challenging and time-consuming. Differences of opinion, domination by certain personalities or interests, lack of an effective facilitator, lack of a set of common goals or purpose and other factors can slow the process, cause attrition by important parties, and overall, lead to an unsatisfactory outcome. Because of these issues, the composition of stakeholder involvement and the use of an effective and informed facilitator are key.

\section{Balanced Stakeholder Representation}

The composition of the stakeholder group is important because the most effective outcome will be the result of active participation and agreement from a variety of interests. It can be challenging to get stakeholders to the table in the first place, particularly state regulators who may not have a regulatory mandate or budget to participate. Barriers to participation, such as lack of interest, lack of understanding or lack of funding, must be identified in the beginning and successfully addressed so that the stakeholder group is composed of a balanced representation of state regulators (at a high enough level to be able to make decisions, or recommend positions to their decision-makers), market participants, potential system users, and public interest organizations.

\section{Facilitation}

The role of the facilitator is equally important and can make the difference between a satisfactory and unsatisfactory outcome. The role of the facilitator should not necessarily be to forge agreement at all costs. This type of mandate is likely to lead to the creation of a REC-tracking system that serves no interests well. Rather, the facilitator should be knowledgeable about different options and alternatives and be able to devise or help the group devise creative compromises that serve the majority of purposes and interests. Absolute consensus on all issues by all parties may not be possible. 


\section{Process Management and Administration}

In addition to finding a knowledgeable and effective facilitator, there is a significant managerial and administrative function involved in designing and developing a REC tracking system through a multi-state stakeholder process. The facilitator may fulfill this function, or the job may fall to a consulting firm or a participating stakeholder organization. In any case, the administrative support staff should be a part of a larger institutional body that is the designated institutional home for the decision-making process. Since the creation of a REC tracking system involves many complicated and challenging issues, the stakeholder group will need additional information, research, new ideas, and someone to complete assigned tasks in between meetings that will support decision-making and keep the process moving along at a fast clip. There is also a large role for recording minutes, setting up meetings, hosting conference calls, and generally fulfilling the administrative needs of the process. The administrative support staff must have budgeted time available to provide this managerial and administrative support, or the process is likely to languish.

\section{Tracking System Design Principles}

There are several core functions that REC tracking systems should satisfy. At the simplest level, these include issuing certificates, tracking their ownership, and retiring them after they have been used to meet government mandates or retail sales; A REC tracking system should also be able to prevent double counting, double sale or double use, ensure the basic information (e.g., fuel type, emissions profile) and quantity of certificates is verified, meet a variety of regulatory objectives, such as verification of compliance with RPS or desire to increase market penetration for renewables, and communicate with other tracking systems so that interregional trade of certificates is possible. The system should be easy to use, transparent, and flexible.

The following design principles should help maximize the usefulness of REC tracking systems.

\section{Generator Registration}

Any generator that is involved in a REC tracking system should be required to fully opt-in to the system. This will ensure that multiple certificates are not issued for a single MWh. A national generator registration could keep track of which accounting system a specific generator is registered with and thus prevent a generator from signing up with more than one accounting system.

\section{Public Acceptance}

Public acceptance of the tracking system — and of the process for developing the system — is important to its success. Involving diverse stakeholders (market participants, non-governmental organizations and government) will help ensure confidence in the system and increase the likelihood of its use. The development of a system without such cooperation could result in a system that does not meet the needs of all stakeholders or potential participants. 


\section{Institutional Support}

State policy makers and private stakeholders should ensure that REC system development has adequate resources and institutional support to succeed. The institutional or administrative home for system operation should be independent of the market (to avoid conflicts of interest), credible to stakeholders, and experienced in handling large quantities of data. In addition, the institutional home of the RECs tracking system should have the ability to periodically review management and operational issues with stakeholders, and make adjustments to system design and operation to accommodate unforeseen issues or changes in the marketplace.

\section{Policy-Neutral}

A general rule of thumb is that REC tracking systems should be policy-neutral to the extent possible so that they can support a variety of public policies and voluntary market needs. Planners should not imbed policy decisions into the design of the tracking system in a way that limits the use of the tracking system for voluntary markets or other purposes. Sufficient information should be tracked so that regulators can make their own determination about REC use or eligibility for public programs. Finally, maintaining a policy-neutral stance is also important to encourage neighboring states to participate in a regional system.,

\section{Geographic Scope}

Like all markets, REC markets need volume in terms of supply and demand to ensure liquidity and competition. Without an ample number of market participants, markets simply will not have enough activity to sustain interest and will cost more than it is worth to those who do participate. Therefore, a REC tracking system should be broad in scope and include several states with mandatory and voluntary green markets to provide sufficient supply of and demand for RECs.

\section{Import and Export Capability}

The REC tracking system should have the ability to track imports and exports of RECs between regions. This helps create market liquidity and helps prevent double counting of RECs that are sold across tracking system boundaries. Ensuring that cross-boundary sales are properly handled is critical to the underlying credibility of REC markets and to the value of RECs in different regional markets. Lack of clarity on these issues could retard investment and contracting for renewable generation. REC tracking systems should also seriously consider membership in the NAAIB. Participation in the cooperative agreements and decision-making process of the NAAIB will lead to standardization and maximum compatibility of REC tracking systems.

\section{Data Integrity and Security}

The information contained in REC tracking systems should be secure from outside intrusion or tampering. Public information should be transparent and easily accessible, while proprietary information should be secure from unauthorized access. Data integrity and security is fundamental to the creation of REC markets that are competitive and free from gaming. The level of security should be at least as secure as the data systems used for energy markets and 
settlements. In addition, information entered into the system (e.g., generation characteristics) should be verified and have a high level of accuracy. Similarly, there should be mechanisms in place to regularly update generator information that is variable, such as fuel types for biomass plants, and appropriate penalties for misrepresentation of information.

\section{Low Transaction Costs}

REC tracking systems should minimize the cost of use to market participants. Low transaction costs are beneficial whether participation in the system is mandatory or voluntary. If the system is mandatory, low transaction costs help reduce the cost of compliance with the RPS or other requirements. In voluntary REC markets, high transaction costs will be a barrier to participation. Therefore, keeping costs low encourages parties to use the system (ultimately best for the credibility of REC markets) and ensures a steady volume of users paying into the operational costs of the system.

\section{Independence from Markets}

If REC tracking systems are asked to create trading opportunities as well as to track ownership of RECs, adequate safeguards should be in place to ensure that the independence and credibility of the tracking function not be compromised. Data confidentiality should be preserved. System administrators should not have a commercial interest in the market, otherwise their access to confidential information about market participants' positions would give them significant competitive advantage. The method of compensation should be carefully designed to avoid unintentional outcomes such as artificial churning.

\section{Conclusions}

The NWCC strongly supports the development of regional renewable certificate-based tracking systems that can meet the many market and regulatory needs of renewable generators and other market participants. Planners should be aware, however, that tracking system design details make a huge difference as to whether the system helps or hinders renewable markets. A welldesigned REC tracking system can support many regulatory and market functions, and will allow new opportunities to expand. By contrast, a poorly designed system, or one that does not contemplate certificate-based tracking, can stifle new markets and place limitations on renewable trading.

The most challenging system design details relate to the nexus of policy and functionality of the system. A well-designed tracking system should be able to meet several policy objectives but it may not be the right tool to meet all policy objectives. The preferred alternative is to design a tracking system that focuses on accounting and information management in the most policyneutral and simple fashion possible. If the information is secure, meticulously tracked and has a high level of accuracy, regulators can use such information to implement and verify a variety of renewable policies, without imbedding their own state policy into the tracking system design.

Another general set of challenges related to REC tracking system design are administrative. 
Coordination among states, stakeholders and existing tracking bodies is a big task and requires a strong institutional home, a decent budget and an effective planning and decision-making process. Although it is difficult to get all three factors to converge, anticipating these needs in advance will help ensure that new initiatives are prepared and launched successfully.

Finally, market conditions matter to the success of a RECs tracking system. There should be a perceived need by market participants, and a sufficient number of potential buyers and sellers (including renewable generators) to support REC liquidity and price discovery. Usually, these circumstances dictate that the REC tracking system should be regionally focused with as broad a geographic scope as possible, and should support both mandatory and voluntary renewable markets. Last but not least, state regulators and policy-makers should demonstrate strong interest so that stakeholders know their work will be taken seriously. 


\section{Bibliography}

California Energy Commission. Renewable Portfolio Standards Proceedings, Phase 2 Implementation May 13, 2003 Workshop, Background Materials, May 2, 2003. Sacramento: California Energy Commission, 2003. http://www.energy.ca.gov/portfolio/documents/2003-0513_WORKSHOP_ACCTNG.PDF

Fitzgerald, Garrett, Ryan Wiser and Mark Bolinger, The Experience of State clean Energy Funds with Tradable Renewable Certificates. Lawrence Berkeley National Laboratory and Clean Energy States Alliance, 2003. Available at http://www.cleanenergystates.org

Grace, Robert and R. Wiser, PhD. Transacting Generation Attributes Across Market Boundaries: Compatible Information Systems and the Treatment of Imports and Exports, November 2002. Berkeley: Ernest Orlando Lawrence Berkeley National Laboratory, 2002. Technical report number LBNL-51703. Available at: http://eetd.lbl.gov/ea/ems/reports/51703.pdf

Green-e, Green-e National Tradable Renewable Certificate (TRC) Standards, no date. Available at http://www.green-e.org/pdf/trc standard.pdf

Hamrin, Jan PhD. and Meredith Wingate. Developing a Framework for Tradable Renewable Certificates, Version 2.4, August 2002. San Francisco: Center for Resource Solutions, 2002. Available at: http://www.resource-solutions.org/TRCAAIB.htm

Hamrin, Jan PhD. and Meredith Wingate. Regulator's Handbook on Tradable Renewable Certificates, May 2003. San Francisco: Center for Resource Solutions, 2003. Available at: http://www.resource-solutions.org/RegulatorHandbook.htm

Hanson, Craig and Vince Van Son, Renewable Energy Certificates: An Attractive Means For Corporate Customers To Purchase Renewable Energy. Washington, DC: World Resources Institute, 2003. Available at http://www.thegreenpowergroup.org/publications.html

National Association of Attorneys General, Environmental Marketing Guidelines for Electricity. 1999. Available at http://www.eere.energy.gov/greenpower/naag 0100.pdf.

National Association of Attorneys General, Memorandum from NAAG Environmental Marketing Subcommittee, January 10, 2000. Available at http://www.eere.energy.gov/greenpower/naag 0100 pr.html

National Wind Coordinating Committee, Consensus Credit Trading Opportunities and Guidelines. 2001. Available at http://www.nationalwind.org/pubs/default.htm

Rackstraw, Kevin, John Palmisano, Michael Ashford, and Amy Ellsworth, Credit Trading and Wind Power: Issues and Opportunities. Washington, DC: National Wind Coordinating Committee, 2001. Available at http://www.nationalwind.org/pubs/default.htm 
NWCC REC Tracking System Design Guide

Rader, Nancy and Scott Hempling. The Renewable Portfolio Standard: A Practical Guide. Washington: National Association of Regulatory Utility Commissioners, February, 2001. Available at http://www.naruc.org/associations/1773/files/rps.pdf

Solar Energy Business Association of New England, Renewable Generator Certificate Trading Handbook. Prepared for Massachusetts Renewable Energy Trust, 2003. Available at http://www.sebane.org 